\title{
Transactional Impediments to Entrepreneurship: A Cross Nation Comparison.
}

\author{
Aashiq Hussian Lone*, Parvez Ahmad**, Nazir Ahmad Nazir*** \\ * Junior Research Fellow (JRF), Deptt of Business \& Financial Studies, University of Kashmir. \\ ** Assistant Professor, Deptt of Business \& Financial Studies, University of Kashmir. \\ *** Professor \& Ex-Head, Deptt of Business \& Financial Studies, University of Kashmir.
}

\begin{abstract}
The art of entrepreneurship is considered critical to the growth and development, given its profound impact on the wealth creation and employment generation. Entrepreneurs in China and India are characterized by unique differences in their motivations for starting a business, whether it has to do with money, social impact, or the role their families play in their decision. The central feature of China's transition from a centrally planned economy is the development of the non-state sector led by an emerging class of the entrepreneurs. On the other hand it is claimed that entrepreneurship has been embedded in the Indian genius and is a part of its tradition. India has been called an entrepreneurial society having incredible entrepreneurial skill. However, numerous impediments mar the prospect of reaping the desired benefits from entrepreneurship for both the countries. This paper makes an effort to revisit the efforts and measures taken by both the countries using decadal 'Doing Business' report of World Bank and how far these actions have made a discernible dent in the inhibitors to entrepreneurship.
\end{abstract}

Key Words: Entrepreneurship, Planned Economy, Entrepreneurial Society.

\section{Introduction}

Entrepreneurship is a critical component of regional development and fostering entrepreneurship is one of the principal measures to accelerate economic and social development (Ryan 2010). Entrepreneurship involves risk taking, being innovative as well as using knowledge and skills to set-up new ventures or diversify from existing ones (Daron, 2004). Entrepreneurship adds significant value to the economy by creating wealth and generating employment. Entrepreneurs innovate and innovation is central ingredient in economic growth. Rightly argued by Peter Drucker that, "the entrepreneur always searches for change, responds to it, and exploits it as an opportunity." According to 2012 Summary Results of the Global Entrepreneurship Monitor (GEM) project, "Regardless of the level of the development and firm size, entrepreneurial behaviour remains a crucial engine of innovation and growth for the economy and for individual companies since, by definition, it implies attention and willingness to take advantage of unexploited opportunities." To promote entrepreneurship we need to know the barriers that affect entrepreneurship in order to overcome them and promote new policies and measures to create new ventures (Susana, 2004). And as argued by Mohnen \& Roller (2005), a critical prerequisite for nurturing entrepreneurship is the creation of a favourable business environment which is reflected by the smooth flow of information; ease of starting a business and obtaining various clearances and permits; ease of filing taxes; an efficient legal system; enabling legislations and regulations; absence of corruption; and world-class infrastructure facilities. The degree to which these facilitating factors are lacking in an economy would mirror the extent of transactional impediments to entrepreneurship.

There is no dearth of classification in the literature when it comes to enumerate the various impediments to entrepreneurship. Peeping through the literature one comes across the micro and macro classification (Van et al 2008); social, political and economic classifications (Shapero, 1982) to name a few. This paper makes an attempt to make a synthesis of these classifications and thus bifurcates the common inhibitors into Regulatory; Cultural and social, and Economic and financial barriers. Regulatory barriers include fiscal and monetary policies, which are essential to provide a basis for a stable macroeconomic environment. They also include structural policies that determine the overall economic framework in which the business sector operates, such as those affecting labour markets, tax design, competition, financial markets and bankruptcy laws (Djankov et al 2002). There is also considerable evidence in the literature that regulatory and administrative burdens can impose adversely on entrepreneurial activity (Evans 1989; John 2002). In some countries, the entrepreneurs need one day to register an enterprise, in others; they need 20 weeks (Fisman, 2003). Regulation of entrepreneurs in some countries limits management flexibility and leads to smaller firm size and less research and development as well as less investment in technology (Kumar et. al, 2002). Creating a business environment conducive to entrepreneurship and enterprise creation therefore requires a broad range of reinforcing and supportive policies as suggested in literature (see for example Barro et. al, 2000). 
Creating an enterprise is a very difficult task because it demands knowledge of the prevalent culture and social norms. To install an enterprise in a foreign country, the entrepreneurs need to know the local language to have a better implementation and adaptation (Simon \& Bonini 1958). The lack of information in the foreign country is also a barrier for the creation of enterprises because entrepreneurs don't have enough information about the role, services and mission of that country (Phillip et. al 2002). Cultural and social barriers also include fear of failure that still remains implanted in many countries because the legal and social consequences of failure are severe (Mohen and Rosa, 2002). Information, communication, role models and resources are very important tools that can help an entrepreneur to overcome these barriers. In order to improve the business environment for the prospective entrepreneurs, entrepreneurial culture needs to be fostered with the aim of enhancing the motivation of persons, the appetence towards risk, the appropriate skills and knowledge and other factors inhibiting the creation of enterprises (Rajan, Raghuram and Luigi 2003; Mohan 2005)

Access to finance is important for all firms in achieving their business objectives; particularly for startups and business that seek to invest and grow (Peterson, 2002). The capital markets tend to be efficient to larger firms but newer and smaller growth firms often depend upon external sources of finance and can face barriers in the market. Khanna (2010) argues that capital markets support bigger firms and are not used to support small enterprises. The smaller firms don't have access to bank credits and face severe difficulties in getting loans (Desai et. al 2003).

\section{Need For The Study}

Given the increasing significance and visible impact of entrepreneurship in wealth-creation and employment-generation, as indicated in foregoing literature, it can be summed up that entrepreneurship is one of the critical factors to the growth and development of a country. Therefore need of the hour is to foster a favourable entrepreneurial ecosystem to reap the desired benefits. This objective is expected to be achieved effectively if we have the prior knowledge about the various barriers coming in the way of entrepreneurship. The knowledge about these barriers may go a long way in helping the policy makers to craft the appropriate policies and measure in order to tame them. Moreover best practices prevalent in this regard in other countries are also possible to provide a bigger opportunity for framing the suitable policies for the growth and development of entrepreneurship. Particularly the countries in the neighbourhood will be of immense relevance, importantly given the cultural, social and related similarities. As such the present study is an attempt to unravel the best practices in the realm of entrepreneurship prevalent in India and China and what need to be done in order to improvise the business environment by comparing both economies against a benchmark country i.e., Singapore. The need of the comparison is to map the transactional impediments in India and China and how the prevalent practices are affecting to entrepreneurial environment in both the countries. Against this backdrop this study intends to unearth the barriers to entrepreneurship and importantly plug the loopholes in the existing literature. More specifically the study aims at achieving the objectives as indicated below:

\section{Objectives}

The chief objectives of the research will encompass the following:

1. To identify the (transactional impediments) factors inhibiting the prospective entrepreneurs in the sample countries;

2. To make a comparative analysis of entrepreneurial barriers in China and India against a benchmark country i.e., Singapore; \&

3. To suggest, on the basis of study results, ways for minimising the impediments in order to stimulate youth to take entrepreneurship as an occupational choice.

\section{Methodology}

Economies are ranked on their ease of doing business, from 1 to 178, with first place being the best. A high ranking on the ease of doing business means the regulatory environment is conducive to new business operations. Taking cue from this measure, we have restricted the variables to three essential start-up concerns: Starting a Business, Enforcing Contracts, and Resolving Insolvency. Data were obtained from Doing BusinessThe World Bank Group. The present study has attempted to put both Chinese and Indian business environment on a comparative test vis-a-vis to one of the most efficient economies in Asia which also happens to be the topperformer in the 'ease' of Doing Business report, i.e., Singapore. Today, Singapore has a highly developed market-based economy, based historically on extended entrepôt trade. Along with Hong Kong, South Korea and Taiwan, Singapore is one of the original 'Four Asian Tigers'. The Singaporean economy is known as one of the freest, most innovative, most competitive, and most business-friendly. The 2011 Index of Economic Freedom ranks Singapore as the second freest economy in the world, behind Hong Kong. Singapore attracts a lot of foreign direct investment because of its location, corruption-free environment, skilled workforce, low tax rates and advanced infrastructure. There are more than 7,000 multinational corporations from the United States, 
Japan, and Europe in Singapore. There are also 1,500 companies from China and 1,500 from India. Roughly 44 percent of the Singaporean workforce is made up of non-Singaporeans. These facts and figures support our rationale to measure the Indian and Chinese business environment against Singapore.

\section{Starting a Business}

\section{Discussions}

Doing Business records all procedures that are officially required for an entrepreneur to start up and formally operate an industrial or commercial business. These include obtaining all necessary licenses and permits and completing any required notifications, verifications or inscriptions for the company and employees with relevant authorities. The ranking on the ease of starting a business is the simple average of the percentile rankings on its component indicators. After a study of laws, regulations and publicly available information on business entry, a detailed list of procedures is developed, along with the time and cost of complying with each procedure under normal circumstances and the paid-in minimum capital requirements. Subsequently, local incorporation lawyers, notaries and government officials complete and verify the data.

The following table clearly shows that Indian scenario looks grim and non-conducive in the year 2004 for the then prospective entrepreneurs on time and cost variables, however, China and Singapore portrays a much better outlook and encourage figures. It took mammoth 89 days in India to an entrepreneur to commence a business given the cumbersome and unnecessary procedures, however on the other side of the aisle, picture in China and Singapore looks comparatively better, where the corresponding figures merely stand at 48 days and just 8 days respectively.

Table I: Starting a business in the three nations under study

\begin{tabular}{|c|c|c|c|c|c|c|c|c|c|}
\hline & \multicolumn{4}{|c|}{ India } & \multicolumn{4}{c|}{ China } & \multicolumn{3}{c|}{ Singapore } \\
\hline Year & Procedures* & Time** & Cost*** & Procedures & Time & Cost & Procedures & Time & Cost \\
\hline 2004 & 11 & 89 & 53.4 & 13 & 48 & 17.8 & 7 & 8 & 1 \\
\hline 2005 & 11 & 89 & 49.5 & 13 & 48 & 15.9 & 7 & 8 & 1 \\
\hline 2006 & 11 & 71 & 62 & 13 & 48 & 13.6 & 6 & 6 & 0.9 \\
\hline 2007 & 11 & 35 & 78.4 & 13 & 35 & 9.3 & 6 & 6 & 0.8 \\
\hline 2008 & 13 & 33 & 74.6 & 13 & 35 & 8.4 & 5 & 5 & 0.8 \\
\hline 2009 & 13 & 30 & 70.1 & 14 & 41 & 8.4 & 4 & 4 & 0.7 \\
\hline 2010 & 13 & 30 & 66.1 & 14 & 38 & 4.9 & 3 & 3 & 0.7 \\
\hline 2011 & 12 & 29 & 56.5 & 14 & 38 & 4.5 & 3 & 3 & 0.7 \\
\hline 2012 & 12 & 29 & 46.8 & 14 & 38 & 3.5 & 3 & 3 & 0.7 \\
\hline
\end{tabular}

Source: Doing Business (IBRD-IFC)

* Procedures to legally start and operate a company (number)

** Time required to complete each procedure (calendar days)

*** Cost required completing each procedure (\% age of income per capita)

However the state of affairs in India has changed dramatically in the aftermath of financial year 20052006, thanks to the $2^{\text {nd }}$ generations reforms that unleashed the beginning of entrepreneurial era in the Indian business landscape. These reforms have unlocked India's enormous growth potential and unleashed powerful entrepreneurial forces. These reforms inter alia appertained to the information technology putting the country significantly on the e-governance map. Resorting to IT minimised the hitherto cumbersome paper work which used to create inordinate delays in the permission clearances, business registrations and other areas related to business starting. China too showed an appreciable time-cutting measures post 2006. This development can be attributed to the change in mindset among the policymakers of China from long-term centrally-planned system to a much better decentralised political decision making framework. The process of dismantling cumbersome and hectic regulatory frameworks in the aftermath of 2002-2003 yielded spectacular results. By the end of 2004 China had become the biggest FDI developing country. In 2003 foreign fund and enterprises produced about $45 \%$ of China's exports. By comparison, China's imports and exports account for $5.3 \%$ and $5.8 \%$ of the worlds, respectively. Foreign exchange, on the other hand, totalled about US\$ 609.9 billion in 2004 (IMF Report 2004). In the pre-reform period all enterprises were owned by the government in a planned economy framework. The heads of the enterprises were designated by officials, not based on performance, but on how lucky you were. They were not efficient entrepreneurs. Following a gradual and on-going shift from a planned economy to a market system, unprecedented changes of ownership in enterprises were carried out. Entrepreneurs, who constituted an emerging class, were at the forefront of economic activities, and even of political affairs. This would have been hard to imagine under the planned economy system. So, a new law called "the non-stateowned economies" comprising 36 items was enacted in March 2004. This law opened the flood-gates to the prospective entrepreneurs to do the business conveniently much to the advantage of country aiming to become 
the economic powerhouse of the world. Back to India, in 2011, in a bid to further stimulate entrepreneurship, India eased regulations for business start-up by establishing an online VAT registration system and replacing the physical stamp previously required with an online version. This development boosted the perception about the ease of starting a business in the country rightly reflected by Table I, where number of procedures, time involved and costs incurred to start a business have plunged many notches.

The occasional business reforms in both the countries, barring from few hiccups have positively changed the business environment year on year as depicted by the Table I. We could see the time period descending (See Chart I) from 71 days to impressive 29 days in India; similarly it has reached notable 38 days from the overtly 48 days in China. However Singapore depicts a favourable business environment as reflected by lesser number of procedures, minimum day's involved and least cost expenditure in starting a business. This supremacy in the business environment is propelled by a number of factors which other two economies either do not possess or possess with lower degree. As substantiated by American-born businessman Jim Rogers, recognized as one of the giants of Wall Street, who moved to Singapore in 2007 as:

"If you were smart in 1807 you moved to London, if you were smart in 1907 you moved to

New York City, and if you are smart in 2007 you move to Asia... Singapore 40 years ago was a swamp with a half a million people. Singapore now, 40 years later, is the country with the largest foreign currency reserve per capita of any country in the world.... It's got the best education in the world, the best health care in the world. It's astonishing to come to Singapore and see that everything works.... Singapore is going to be the financial centre of Southeast Asia, probably Asia, and likely one of the top financial centres' of the world."

Therefore with the aim of becoming the economic powerhouse powered by strong entrepreneurial ecosystem, it is imperative for both India and China, in the light of the operating constraints, to adopt the best practices adopted by the Singapore in their business realms. Data in Table I is depicted by Figure in Annexure I.

\section{Enforcing Contracts}

Indicators on enforcing contracts measure the efficiency of the judicial system in resolving a commercial dispute. The data are collected through study of the codes of civil procedure and other court regulations as well as surveys completed by local litigation lawyers and by judges. The ranking on the ease of enforcing contracts is the simple average of the percentile rankings on its component indicators.

Table II: Enforcing Contracts in the three nations.

\begin{tabular}{|c|c|c|c|c|c|c|c|c|c|}
\hline & \multicolumn{3}{|c|}{ India } & \multicolumn{3}{c|}{ China } & \multicolumn{3}{c|}{ Singapore } \\
\hline Year & Procedures* & Time** & Cost*** & Procedures & Time & Cost & Procedures & Time & Cost \\
\hline 2004 & 46 & 1420 & 39.6 & 35 & 406 & 11.1 & 21 & 120 & 17.8 \\
\hline 2005 & 46 & 1420 & 39.6 & 35 & 406 & 11.1 & 21 & 120 & 17.8 \\
\hline 2006 & 46 & 1420 & 39.6 & 35 & 406 & 11.1 & 21 & 120 & 17.8 \\
\hline 2007 & 46 & 1420 & 39.6 & 35 & 406 & 11.1 & 21 & 120 & 17.8 \\
\hline 2008 & 46 & 1420 & 39.6 & 35 & 406 & 11.1 & 21 & 120 & 17.8 \\
\hline 2009 & 46 & 1420 & 39.6 & 34 & 406 & 11.1 & 21 & 150 & 25.8 \\
\hline 2010 & 46 & 1420 & 39.6 & 34 & 406 & 11.1 & 21 & 150 & 25.8 \\
\hline 2011 & 46 & 1420 & 39.6 & 34 & 406 & 11.1 & 21 & 150 & 25.8 \\
\hline 2012 & 46 & 1420 & 39.6 & 34 & 406 & 11.1 & 21 & 150 & 25.8 \\
\hline
\end{tabular}

Source: Doing Business (IBRD-IFC)

* Procedures to enforce a contract through a court (number)

** Time required to complete procedure (calendar days)

*** Cost required completing each procedure (\% age of claim)

It is a common belief that well-functioning courts help businesses expand their network and markets. Without effective contract enforcement, people might well do business only with family, friends and others with whom they have established relationships. Where contract enforcement is efficient, firms are more likely to engage with new borrowers or customers, and they have greater access to credit. In this backdrop Table II paints a shabby picture of Indian judicial system when it comes to the effectiveness and efficiency of adjudication visa-vis to China and bench mark country, i.e., Singapore. The table reveals that hectic 46 procedures in the year 2004 take a minimum of 1420 days an average in India to enforce a particular contract, in comparison only 406 days are spent to complete 35 procedures in China. And the scenario in Singapore is far better where it consumes merely 120 days to complete only 21 procedures with minimum costs to enforce a contract. The Indian picture has remained unaltered (See Table II) until 2012, indicating that no reforms have been introduced to make a visible dent in the pendency. 
It is noteworthy that Pendency has increased by $148 \%$ in the Supreme Court, $53 \%$ in High Courts and $36 \%$ in subordinate courts in the last 10 years. The Union Law Minister, in his reply to a question in Lok Sabha, spoke about the reasons for increase in pendency. These include: (i) increase in institution of fresh cases; (ii) inadequate number of judges and vacancies; (iii) inadequate physical infrastructure and staff; and (iv) frequent adjournments. Over the past few years, some measures have been taken by the government to facilitate expeditious disposal of cases. These include schemes for computerisation, infrastructural augmentation, promotion of Alternate Dispute Resolution mechanisms, etc. Despite these initiatives, the rate of case disposal has not kept pace with the rate of case institution. As a result, the total number of pending cases has increased. Between October 2009 and October 2010, subordinate courts settled 1.73 crore cases as compared to 1.24 crore in 1999, an increase of 49 lakh. During the same period, the fresh cases filed increased by 52 lakh. Recognising the impoverished adjudication system damning the business perception in the country, the Union Law Minister recently launched the 'Mission Mode Programme for Reduction of Pendency of Arrears in Courts'. According to media reports, the programme aims to dispose of 40 per cent of the cases pending in subordinate courts across the country, in the coming six months. Chinese judicial system appears to be perceptibly pro-business (Table II). Doing Business ranking places it at number 18 world over in the category of enforcing contracts. This means China has one of the best systems in the world for enforcement of contracts. Compare that with India, which is rated 180 out of 181 countries, or Brazil, which is rated at 100. It is even better than the United Kingdom, which comes in at 23 and better than Japan, which figures at $21^{\text {st }}$ place. China has responded with what some deem progressive measures in the past few years in the form of The Second Five-Year Reform Program for the People's Courts begun in 2004 with its " 50 Goal Agenda." Inter alia, the Agenda unequivocally pleads for the expeditious disposal of contract suits too. This development has created favourable impact on the costs; time and number of procedures in the aftermath of its implementation (see Table II, 2009 onwards). Apart from India and China, our benchmark country enjoys the overall global rank of 12 in enforcing contracts. This status displays the robustness of the adjudicatory machinery of this country which is par-excellence. The country is a trend-setter in intellectual property protection arena with laws in place that are in tune with the growing business atmosphere of the country. Singapore has become a one-stop centre for businesses seeking to manage their IP assets. The World Economic Forum (WEF), the Institute for Management Development (IMD) and the Political Economic Risk Consultancy (PERC) have all ranked Singapore top in Asia. Not only can Singapore businesses register trademarks in Singapore, they can also file for global trademark registration from Singapore as the country is a signatory to major IP conventions and treaties, such as the Patent Cooperation Treaty, Paris Convention, Berne Convention, Madrid Protocol, Budapest Treaty, Agreement on Trade-related aspects of IP rights, and World Intellectual Property Organisation.

When policy measures are put in the public domain unambiguously, not only the trend towards litigation is arrested but is also allows the courts to adjudicate expeditiously. Therefore both the countries, particularly India needs to introspect deeply about its adjudicatory mechanism to address the anti-business perception of the prospective entrepreneurs and encourage a prompt and responsive judicial system.

\section{Resolving Bankruptcy}

A robust bankruptcy system functions as a filter, ensuring the survival of economically efficient companies and reallocating the resources of inefficient ones. Fast and cheap insolvency proceedings result in the speedy return of businesses to normal operation and increase returns to creditors. By improving the expectations of creditors and debtors about the outcome of insolvency proceedings, well-functioning insolvency systems can facilitate access to finance, save more viable businesses and thereby improve growth and sustainability in the economy overall.

Bankruptcy is a legally declared inability or impairment of ability of an individual or organization to pay its creditors. Creditors may file a bankruptcy petition against a business or corporate debtor ("involuntary bankruptcy") in an effort to recoup a portion of what they are owed or initiate a restructuring. In the majority of cases, however, bankruptcy is initiated by the debtor a "voluntary bankruptcy" that is filed by the insolvent individual or organization. Winding up of company in India at the onset of the 2004, as depicted by Table III, takes a decade to resolution even after the Company has actually been declared insolvent. This state of affairs speaks volume about the outdated and inappropriate laws governing the insolvency. Though in India we come across acts like, Sick Industrial Companies Act, 1985 (SICA), which deals with establishment of the Board for Industrial and Financial and Reconstruction (BIFR) by the Central Government to exercise the jurisdiction and powers, but the functioning of SICA has not been found to be satisfactory as many issues have been identified during its implementation. 
Transactional Impediments To Entrepreneurship: A Cross Nation Comparison.

Table III: Resolving bankruptcy in the three nations:

\begin{tabular}{|c|c|c|c|c|c|c|c|c|c|}
\hline & \multicolumn{4}{|c|}{ India } & \multicolumn{3}{c|}{ China } & \multicolumn{3}{c|}{ Singapore } \\
\hline Year & Time* & Cost** & Recovery*** & Time & Cost & Recovery & Time & Cost & Recovery \\
\hline 2004 & 10 & 9 & 12.1 & 2.4 & 2.4 & 31.7 & 0.8 & 1 & 91.3 \\
\hline 2005 & 10 & 9 & 12.2 & 2.4 & 2.4 & 31.7 & 0.8 & 1 & 91.3 \\
\hline 2006 & 10 & 9 & 12.8 & 2.4 & 2.4 & 31.5 & 0.8 & 1 & 91.3 \\
\hline 2007 & 10 & 9 & 13 & 2.4 & 2.4 & 31.5 & 0.8 & 1 & 91.3 \\
\hline 2008 & 10 & 9 & 11.6 & 1.7 & 1.7 & 35.9 & 0.8 & 1 & 91.3 \\
\hline 2009 & 8.5 & 9 & 12.5 & 1.7 & 1.7 & 35.3 & 0.8 & 1 & 91.3 \\
\hline 2010 & 7 & 9 & 15.1 & 1.7 & 1.7 & 35.3 & 0.8 & 1 & 91.3 \\
\hline 2011 & 7 & 9 & 16.3 & 1.7 & 1.7 & 36.4 & 0.8 & 1 & 91.3 \\
\hline 2012 & 7 & 9 & 20.1 & 1.7 & 1.7 & 36.1 & 0.8 & 1 & 91.3 \\
\hline
\end{tabular}

Source: Doing Business (IBRD-IFC)

*Time required to recover debt (years)

**Cost required recovering debt (\% age of debtor's estate)

***Recovery rate for creditors (cents on the dollar)

There are inherent defects both, procedural and legal in proceedings before BIFR. The BIFR takes substantial time to determine whether a company is sick and thereafter, to formulate a revival strategy. Consideration of the same also takes substantial time since banks and financial institutions have their own hierarchy in decision making, leading to avoidable delays. The position in the Indian insolvency regime received a major fillip post 2002, thanks to Securitization and Reconstruction of Financial Assets and Enforcement of Security Interest (SARFAESI) Act, 2002. Procedures under the 2002 Securitization Act have become more effective in the year 2010, easing the process and reducing the time required to close a business from ten to seven years (See Table III, 2010 onwards). Turning leaf to china, there has been no change in the insolvency regime until 2007. However, China has entered a significant stage in its economic transition with the introduction of a new and seemingly sophisticated bankruptcy law drawing inspiration from mature insolvency systems in the fall 2007. China's New Enterprise Bankruptcy Law clearly presented the structure of China's reformed legal bankruptcy system by introducing the framework and analyzing typical cases which have been or are being heard since the new bankruptcy law was operational. This development is depicted by the subsequent years (See Table III) when time and recovery rates started to show positive changes, giving much needed relief to the business community. Both India and China act poorly in liquidation laws as shown by the Table 3 relative to Singapore, where it takes mere 7-8 months to complete the insolvency proceedings. The Singapore Bankruptcy Act encourages arrangements for the settlement of debt to be explored as a preference to the instigation of official bankruptcy proceedings. The debtor is required to prepare a proposal explaining why a voluntary arrangement would be a better option than a formal winding up procedure, and why creditors may find the proposal to be a better option than bankruptcy, something wanting in India. The nation's parliament passed a bill in the year 2009 that allowed people with debt of as much as $\$ \$ 100,000(\$ 66,600)$ to work out a repayment plan with their creditors without being declared bankrupt, avoiding what the government calls the "attendant disabilities and social stigma" that come with insolvency. Also, Singapore has the world's highest recovery rate for assets of bankrupt companies after Japan. Creditors recover 91.3 cents on the dollar for assets seized from debtors who fall into bankruptcy, compared with 76.7 cents in the U.S., 36.1 in China and meagre 20.1 cents in India. The need of the hour is to reconsider seriously the bankruptcy laws in force in India and China to bring them in tune with the global standards in order to boost the business sentiment in their respective nations.

\section{Key Findings of the Study}

- Time to start business although has reduced over the period in India; however corresponding costs involved have not shown symmetrical downturn in India. China and Singapore both have emerged as the trend setters thanks to the reforms spree undertaken by the concerned countries to boost ease of doing business perception.

- Contract enforcement regime emerges as the major inhibitor to entrepreneurial activity in India added to it the snail's pace reforms or no reforms are adding salt to the injury. Inordinate delay in the adjudication of contract cases in India seems to be one of the biggest business de-motivator.

- Lingering bankruptcy regime is another major impediment in the Indian business scenario where time \& costs involved in the recovery of dues outweighs the benefits a creditor possibly gets after the proclamation of insolvency by the debtor. 
Transactional Impediments To Entrepreneurship: A Cross Nation Comparison.

\section{Conclusion}

While putting the database of World Bank to a rigorous analysis, this paper has dug deeper into the business environment of the countries under study in order to unravel the reforms and other measures, sample countries have taken to halt the impact of inhibitors to productive entrepreneurship. It would be better to call this effort a further extension of what has been done by the World Bank through Doing Business. We have travelled an extra mile in enumerating the policy measures incorporated by both the countries that have virtually dented the impediments marring the potential of entrepreneurship. Extensive efforts have been made to reveal the causes and consequences at the junctions where numbers change positively or otherwise, something Doing Business Report is wanting in. Our effort is expected to boost the understanding for prospective business incubators about the kind of environment prevalent in both the countries and how far both the countries facilitate business start-ups. Also this improved understanding of the business environment prevalent in both the countries may further assist academicians and policy makers in furthering positive reforms spree to yield rich dividends from entrepreneurship.

\section{Annexure-I}

CHART-I: EASE OF DOING BUSINESS IN THE THREE NATIONS

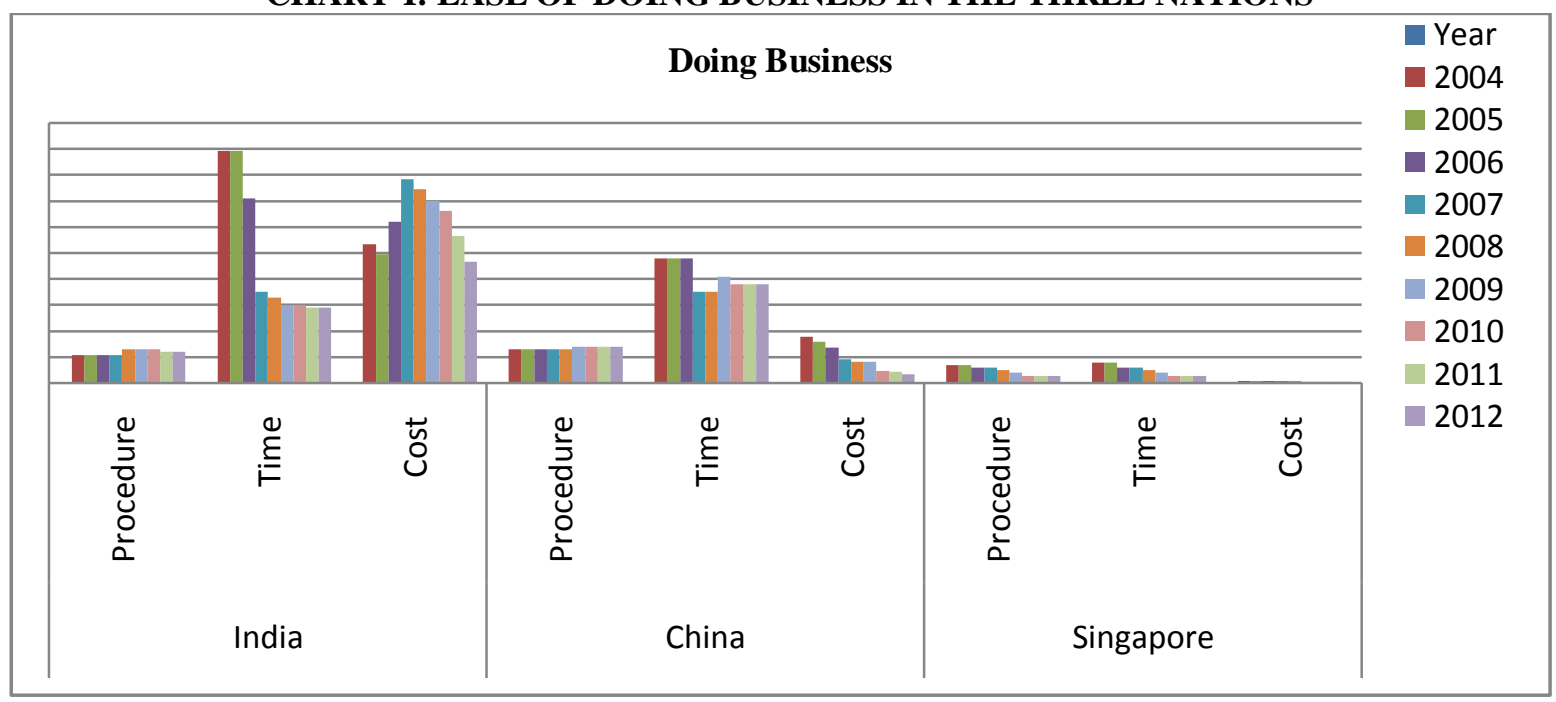

CHART-II: ENFORCING CONTRACTS IN THE THREE NATIONS

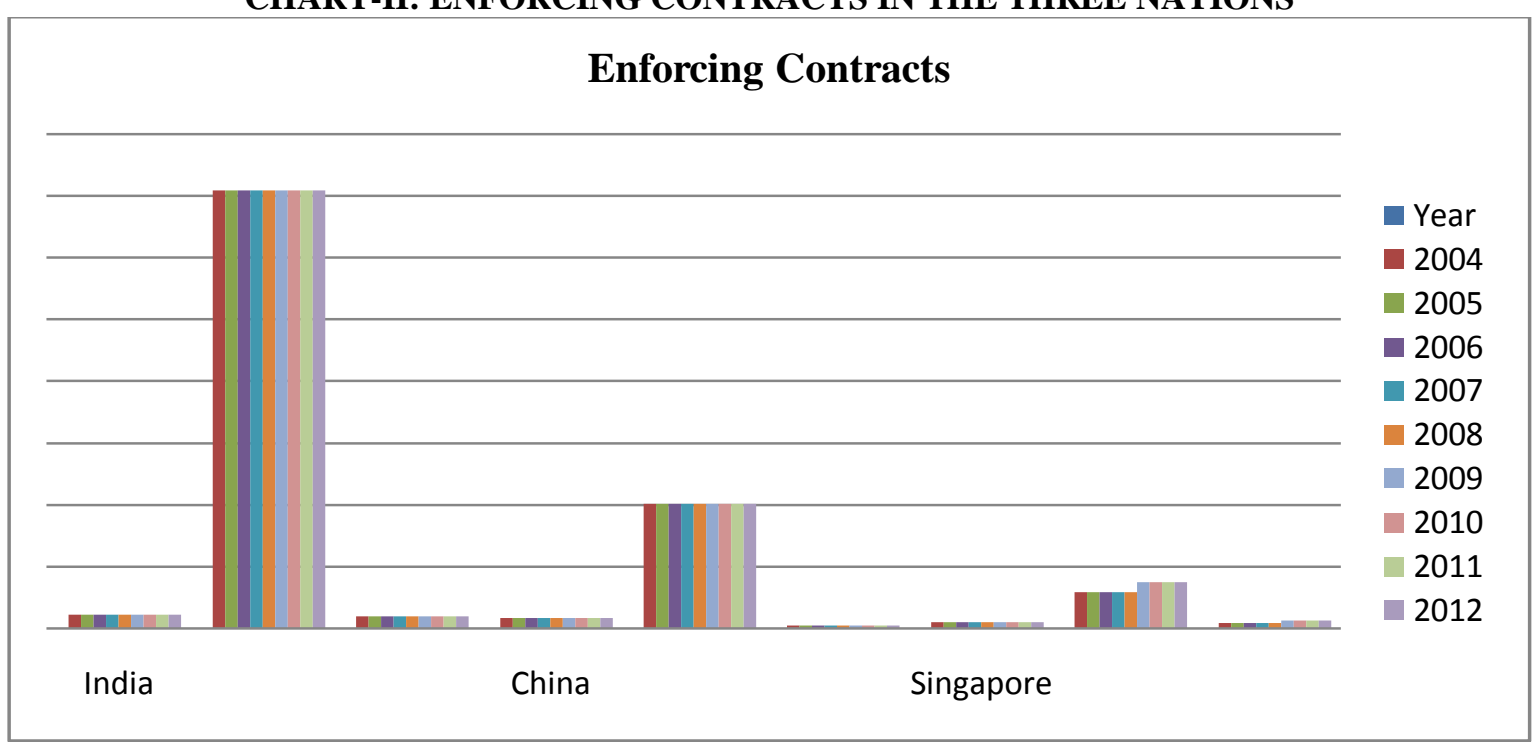




\section{CHART III: RESOLVING INSOLVENCY IN THE THREE NATIONS}

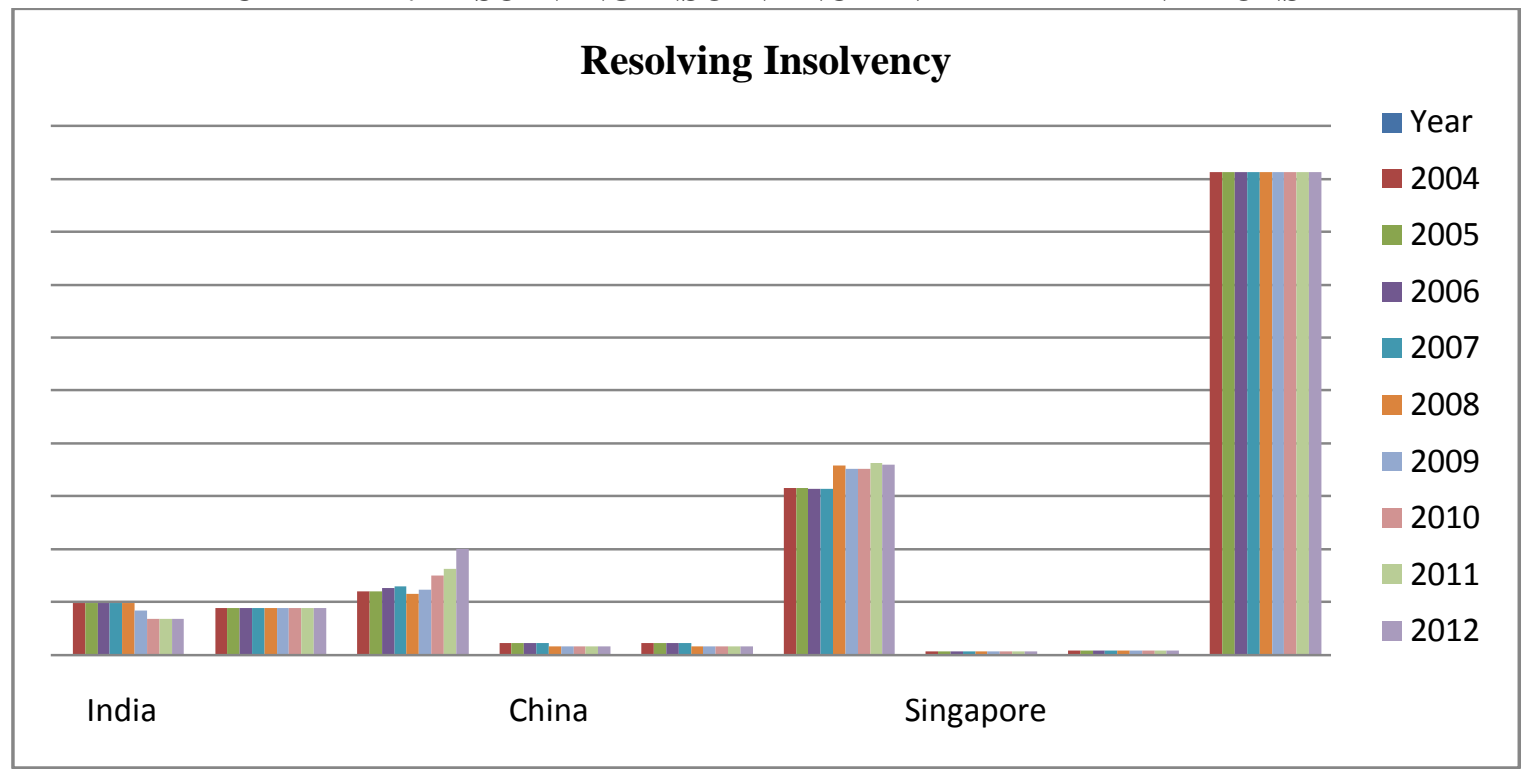

\section{References}

[1]. Barro, Robert J., and Jong-Wha Lee, (2000), International data on educational attainment: Updates and implications, CID Working Paper no. 42, Harvard University.

[2]. Desai, Mihir, Paul Gompers, Josh Lerner, (2003), Institutions, capital constraints and entrepreneurial firm dynamics: Evidence from Europe, NBER Working Paper No. w10165.

[3]. Djankov, Simeon, Rafael La Porta, Florencio Lopez-de-Silanes, and Andrei Shleifer, (2002) The regulation of entry, Quarterly Journal of Economics 117, 1-35

[4]. Evans, David S., and Boyan Jovanovic, (1989), An estimated model of entrepreneurial choice under liquidity constraints, Journal of Political Economy 97, 808-827.

[5]. Fisman, Raymond and Inessa Love, (2003a), Trade credit, financial intermediary development and industry growth, Journal of Finance 58, 353-374

[6]. Fisman, Raymond and Inessa Love, (2003b), Financial dependence and growth revisited, NBER working paper No. 9582, March 2003 b.

[7]. John and John Fingleton, (2002), Entry regulation and influence of an incumbent as special interest group, CESifo working paper no. 787.

[8]. Kumar, Krishna, Raghuram Rajan, and Luigi Zingales, (2002), What determines firm size? mimeo, University of Chicago.

[9]. Mohnen, P. and Röller, L. (2005), "Complementarities in innovation policy”, European Economic Review, Vol. 49, pp. 1431-1450.

[10]. Mohnen, P. and Rosa, J. (2002). "Barriers to innovation in service industries in Canada", Institutions and systems in the geography of innovation, Vol. 21, Pp. 231-250.

[11]. Petersen, Mitchell, and Raghuram Rajan, 2002, Does distance still matter? The information revolution in small business lending, Journal of Finance 57, 2533-2570.

[12]. Rajan, Raghuram and Luigi Zingales, (2003), The great reversal: The politics of financial development in the 20 ${ }^{\text {th }}$ century, Journal of Financial Economics 69 (1), 5-50.

[13]. Ryan Streeter (2010), The Legatum Institute Survey of Entrepreneurs, No. 2010-01 China \& India, Pp. 3-7.

[14]. Scarpetta, Stefano, Phillip Hemmings, Thierry Tressel and Jaejoon Woo (2002), The role of policy and institutions for productivity and firm dynamics: evidence from micro and industry data, Working paper No. 329, Economics department, OECD

[15]. Shapero, A. (1982). "Social dimensions of entrepreneurship." In C. A. Kent, D. L. Sexton \& K.Vesper , The Encyclopedia of Entrepreneurship (pp. 72-90). Englewood Cliffs: Prentice Hall. Social Psychology, Vol. 29(2), Pp. 505-528.

[16]. Simon, Herbert A., and Charles P. Bonini, (1958), The size distribution of business firms, American Economic Review 48, 607617.

[17]. Susana Martins and Catherine Couchi (2004), Barriers to entrepreneurship and business creation, European Entrepreneurship Cooperation, pp 1-12

[18]. Tarun Khanna. (2011) "Billions of Entrepreneurs: How China and India Are Reshaping Their Futures — and Yours"

[19]. Van Gelderen, M., Brand, M., van Praag, M., Bodewes, W., Poutsma, E., \& van Gils, A. (2008). "Explaining entrepreneurial intentions by means of the theory of planned behaviour." Career Development International, Pp. 22-24 